\title{
Study of Effect of Plant Growth Promoting Rhizo Microorganisms on Success Rate of Cashew Grafts
}

\author{
S.N. Ranjani*, L. Krishna Naik and G. Kushala \\ Department of Agriculture Microbiology, University of Agricultural Sciences, \\ G.K.V.K, Bengaluru, Karnataka, India \\ *Corresponding author
}

\section{A B S T R A C T}

Keywords

Plant growth, Rhizomicroorganisms.

\section{Article Info}

Accepted:

28 October 2017

Available Online:

10 December 2017
Azatobacter chroococcum, Bacillus megaterium, Pseudomonas fluorescens, Trichoderma viride and Glomus fasciculatum were found to be efficient PGPR microorganisms. Hence, they were subjected to compatibility test by dual culture method. All the four PGPR microorganisms (A. chroococcum, $B$. megaterium, $P$. fluorescens and $T$. viride) were found to be compatible under in vitro condition both on solid and in liquid media. Population density of inoculated PGPR microorganisms in the cashew rhizosphere at different intervals was found to be maximum in the treatments receiving that organism alone or with other PGPR microorganism. Population density of inoculated organisms increased gradually up to grafting and there after slight decline was noticed.

\section{Introduction}

Cashew (Anacardium occidentale L.) a tropical plant of commercial importance, belongs to the family Anacardiaceae. It is one of the export oriented cash crops of our country. It is believed to be the native of tropical America, from where it was introduced to the Malabar Coast of India by early Portuguese settlers more than 500 years ago. It is a perennial, low spreading tree and can reach to the height of about 15 meters with number of primary and secondary branches. Earlier, it was grown mainly to check the soil erosion, but gradually it has gained commercial importance as a plantation crop and has assumed a prominent position in
Indian economy, as an export oriented crop as it earns lot of foreign exchange.

Application of biofertilizers is known to improve the soil fertility and crop productivity in several crops through atmospheric nitrogen fixation, solubilization of inorganic and organic phosphorus and other nutrients and synthesis of growth regulators. They also play an important role in improving germination, root proliferation and suppress plant diseases (Verma, 1993; SubbaRao, 1995). The beneficial effect of Azotobacter treatment has been reported in establishment of healthy and sturdy seedlings 
(Sundara Rao et al., 1963). Taking into consideration of the above all factors, it was thought appropriate to initiate an investigation on the use of Azotobacter chroococcum, Bacillus megaterium, Trichoderma viride, Pseudomonas fluorescens and the vesicular arbuscular mycorrhizal fungus Glomus fasciculatum, to study their role in nut germination along with other growth characters and also their influence on success rate of grafts which is a major problem in cashew, without chemical fertilizers in raising quality cashew root stocks.

Phosphate solubilizing microorganisms have been reported to solubilize inorganic forms of $\mathrm{P}$ by excreting organic acids that directly dissolve phosphate materials and chelate cationic forms of $\mathrm{P}$ ion (Sperber, 1958 and Katznelson and Bose, 1959). Strobel and Nachmias (1985) reported that application of Agrobacterium to bare root stocks of almond trees resulted in a striking increase in leaf number, stem diameter and shoot elongation during the first growing season no pathological reaction was seen with any of the plants used in their study. Similar positive growth effects were also recorded on initial growth of bare root stock of olive treated with Agrobacterium.

\section{Materials and Methods}

The present investigation on the growth of cashew seedlings and success rate of grafts as influenced by different plant growth promoting rhizomicroorganisms was carried out during the year 2007- 08 in collaboration with All India Coordinated Research Project on cashew, nursery section at Agricultural Research Station (ARS), Chintamani, Kolar (Dist.), Karnataka.

The details of the location of experimental site and methods followed.

\section{Location and climate}

The Agricultural Research Station (ARS), Chintamani is situated on Kolar road about 7 $\mathrm{km}$ away from Chintamani town. It is located at 857 meter above the mean sea level with latitude of $13^{0} 24^{1} \mathrm{~N}$ and longitude of $70^{0} 04^{1}$ E.

The ARS is located in the eastern dry zone of Karnataka which generally receives an average annual rainfall of around $690 \mathrm{~mm}$ mainly distributed from May to November. During 2007 - 08 i.e. during the experimental period $197.5 \mathrm{~mm}$ of rainfall was received. The maximum daily temperature of $34.1^{\circ} \mathrm{C}$ during April and the minimum of $25.3^{\circ} \mathrm{C}$ during December were recorded.

The highest evaporation of $9.8 \mathrm{~mm}$ was in March and the minimum of $3.1 \mathrm{~mm}$ was in December. The highest relative humidity of 81.8 percent was recorded during September and the lowest of 24.4 during March.

\section{Plant Growth Promoting Rhizomicro- organisms (PGPRM)}

PGPR microorganisms used in the study were Azotobacter chroococcum (free living nitrogen fixer), Bacillus megaterium ('P' solubilizing bacterium), Trichoderma viride and Pseudomonas fluorescens (PGPR microorganisms) and Glomus fasciculatum ('P'mobilizer).

\section{Preparation of inocula}

Standard cultures of Bacillus megaterium, Azotobacter chroococcum, Pseudomonas fluorescens and Trichoderma viride were grown as liquid cultures in Nutrient broth, Waksman No. 77 broth, King's B broth and Potato dextrose broth respectively, at $27 \pm 1^{\circ} \mathrm{c}$ on a rotary shaker at $150 \mathrm{rpm}$ for 5 days to get the maximum population. When cell density 
was $10^{9} / \mathrm{ml}$ of the broth culture, it was mixed with the carrier materials such as lignite and talc separately. The carrier based inocula were used for further studies

\section{Polyhouse evaluation}

The experiment on the evaluation of the microbial inoculants was conducted under poly house condition during Kharif season (Plate $4 \mathrm{a}$ and $4 \mathrm{~b}$ ). The experimental details are as follows.

Date of sowing: 11/ 6/ 2008.

Variety: Root stock - Ullal - 1 and Scion Chintamani -1

\section{Design: CRD}

Replications: 12

No of bags per treatment unit: 12

Treatment details:

$\mathrm{T}_{1}$ : control

$\mathrm{T}_{2}$ : Azotobacter chroococcum

$\mathrm{T}_{3}$ : Bacillus megaterium

$\mathrm{T}_{4}$ : Glomus fasciculatum

$\mathrm{T}_{5}$ : Pseudomonas fluorescens

$\mathrm{T}_{6}:$ Trichoderma viride

$\mathrm{T}_{7}$ : Azotobacter chroococcum + Bacillus megaterium

$\mathrm{T}_{8}$ : Azotobacter chroococcum + Glomus fasciculatum

$\mathrm{T}_{9}$ : Azotobacter chroococcum + Pseudomonas fluorescens
$\mathrm{T}_{10}$ : Azotobacter chroococcum + Trichoderma viride

$\mathrm{T}_{11}:$ Bacillus megaterium + Glomus fasciculatum

$\mathrm{T}_{12}$ : Bacillus megaterium + Pseudomonas fluorescens

$\mathrm{T}_{13}:$ Bacillus megaterium + Trichoderma viride

$\mathrm{T}_{14}$ : Pseudomonas fluorescens + Trichoderma viride

$\mathrm{T}_{15}$ : Glomus fasciculatum + Trichoderma viride

Date of grafting: 24/ 8/ 2008.

\section{Observations recorded}

\section{Growth parameters}

\section{Germination percentage}

Germination percentage was recorded on the $30^{\text {th }}$ day after sowing.

\section{Seedling height $(\mathrm{cm})$}

The height of seedlings $(\mathrm{cm})$ was measured from the soil surface in poly bags to the growing point end of the leaves.

This was measured at $45^{\text {th }}, 75^{\text {th }}$ day after sowing and $45^{\text {th }}$ day after grafting.

\section{Number of leaves}

The number of fully opened leaves produced in a seedling was counted at $45^{\text {th }}, 75^{\text {th }}$ day after sowing and $45^{\text {th }}$ day after grafting. 


\section{Stem girth $(\mathbf{c m})$}

The diameter of the stem below the first pair of leaves was measured with the help of Vernier - calipers at $45^{\text {th }}, 75^{\text {th }}$ day after sowing and $45^{\text {th }}$ day after grafting. Finally the girth of the stem was calculated using the formula $\mathrm{C}=2 \pi \mathrm{r}$.

\section{Recovery of graftable root stocks}

Among the total number of germinated seeds in each treatment, the seedlings which have attained more than $25 \mathrm{~cm}$ in height and 1.6 $\mathrm{cm}$ in girth were counted and the rest were rejected and the recovery of good graftable seedlings was expressed in percentage.

\section{Sprout initiation in grafts}

The prepared graft was considered as sprouted, when rudimentary apical bud swollen and leaves were clearly visible.

\section{Success of grafting (\%)}

The number of successful grafts was counted after the complete sprouting and commencement of new growth on scion at $45^{\text {th }}$ day after grafting. Percentage of success was calculated based on the number of grafts prepared.

\section{Root length (cm)}

The root length was measured after depoting and washing the roots thoroughly from the end point of stem to the tip of the root.

\section{Inoculation of PGPRM}

Five grams of lignite based inoculum of plant growth promoting rhizomicroorganism was applied in the poly bag containing soil $(2-3$ $\mathrm{cm}$ below the soil surface), according to the treatment details.

\section{Rising of root stock}

The soaked seeds were sown in poly bags containing $2 \mathrm{~kg}$ of potting mixture with punch holes for drainage. The seeds were sown such that the stalk end facing upwards in polythene bags at about $2-3 \mathrm{~cm}$ below the soil surface. Germination of seeds started 15 days after sowing and continued till $30^{\text {th }}$ day. Regular watering and weeding was attended.

\section{Selection and preparation of seedling (root stock)}

Healthy and vigorously grown seedlings having single main stem were selected for grafting. Seventy five days old seedling grown in the centre of polythene bag were used.

\section{Preparation of scion}

Three to four months old shoots of pencil thickness having terminal dormant buds were selected from the healthy trees and were precured by cutting the leaves keeping only the petiole attached. The scions were immediately wrapped in a wet cloth to avoid desiccation. Precuring was done seven days prior to the actual day of grafting.

\section{Grafting method}

Cashew seedlings (root stocks) grown for 75 days were selected for grafting. Grafting was done by soft wood method. The stock plant with new terminal growth was decapitated at a height varying from $10-18 \mathrm{~cm}$ from soil surface of poly bags and a vertical split of about 3 to $4 \mathrm{~cm}$ was made using a sharp knife and the care was also taken to retain $2-4$ leaves well below the grafting point. A scion of $8-10 \mathrm{~cm}$ length was taken and the basal end was cut into a wedge form $(3-4 \mathrm{~cm}$ long) and the stock in such a way that at least one side of the scion cambium makes 
satisfactory contact with the cambium of root stock. The inserted portion was wrapped firmly with $1.5 \mathrm{~cm}$ wide and $30 \mathrm{~cm}$ long, 100 gauge white transparent polyethylene strip, so as to keep the stock and scion parts in firm contact and to prevent water entering into the grafted portion. A Pepsi poly tube was inserted over the scion to create higher humidity around the grafted portion (Plate 5a and $5 b)$.

Enumeration of inoculated microbial population in the rhizosphere of cashew in nursery (both in root stocks and grafts)

For enumeration of PGPR microbial population, soil sample was collected carefully from the rhizosphere of cashew seedlings at different intervals and population density was determined by soil dilution plate method. Ten grams of the pooled soil sample of each treatment was collected from different replications. Each ten grams of soil was mixed in $90 \mathrm{ml}$ sterilized water blank and mixed thoroughly to give $10^{-1}$ dilution. Subsequent dilutions up to $10^{-6}$ were made by transferring $1 \mathrm{ml}$ to $9 \mathrm{ml}$ water blanks. For enumeration of Azotobacter chroococcum, Bacillus megaterium, Pseudomonas fluorescens and Trichoderma viride, different dilutions were selected. One $\mathrm{ml}$ of suspension from each dilution was transferred aseptically into sterile petriplates. Fifteen $\mathrm{ml}$. of appropriate medium was poured into plates and gently rotated in clockwise and anticlock wise direction to let the suspension distribute uniformly in the medium. Three replications were maintained for each dilution. The plates were incubated at $27 \pm 1^{\circ} \mathrm{C}$ for 5 days and colonies were counted on a colony counter and population was estimated and expressed as CFU per gram dry weight of soil (Johnson and Curl, 1972).

The population of above said organisms was estimated at 30, 60 days after sowing and 30,
60 day after grafting (Note: During the estimation of Bacillus spp., the soil suspension was subjected to simmering for 10 minutes).

\section{Procedure for enumeration of VAM spores}

Fifty grams of rhizosphere soil was suspended in $500 \mathrm{ml}$ of water and shaken thoroughly.

After the sedimentation of course sand, the suspension was decanted over a series of test sieves (a sieve set with $1 \mathrm{~mm}$ pore size $350 \mu \mathrm{m}, 250 \mu \mathrm{m}, 180 \mu \mathrm{m}$ and $45 \mu \mathrm{m}$ arrange in the descending order). Then the content of $108 \mu \mathrm{m}$ and $45 \mu \mathrm{m}$ sieve were carefully washed into a conical flask it was shaken and allowed to settle for $30 \mathrm{sec}$ and spores were trapped on a nylon mesh of $40 \mu \mathrm{m}$ placed on a sieve. The nylon mesh was then transferred on to a glass petri plate the number of spores was then counted under stereomicroscope and expressed as spore number/ 50g dry soil.

\section{After care of the grafts}

The grafted plants were kept in poly house and watered regularly. The grafts sprouted in 11 - 18 days' time. The polythene cap was removed at this stage.

\section{Results and Discussion}

The results of the experiment conducted on cashew to study the effect of inoculation of plant growth promoting rhizomicroorganisms (PGPRM) on cashew rootstock growth and success of grafting, are presented in this chapter (Table 1 and 2).

\section{Recovery of graftable seedlings}

The data on recovery of graftable seedlings 75 DAS, number of days taken for sprout initiation in scion and success of grafts are presented in Table 2. 
Table.1 Initial microbial population in the soil sample used for the study

\begin{tabular}{|l|l|l|}
\hline SI. No & \multicolumn{2}{|c|}{ Initial microbial population of soil } \\
\hline 1 & Bacteria & $23.00 \times 10^{5}$ \\
\hline 2 & Fungi & $10.50 \times 10^{4}$ \\
\hline 3 & Actinomycetes & $8.50 \times 10^{3}$ \\
\hline 4 & Azotobacter spp. & $10.50 \times 10^{3}$ \\
\hline 5 & Bacillus spp. & $13.50 \times 10^{5}$ \\
\hline 6 & Trichoderma spp. & $9.00 \times 10^{2}$ \\
\hline 7 & Pseudomonas spp. & $9.50 \times 10^{3}$ \\
\hline 8 & VAM & 18.00 spore/50g dry soil \\
\hline
\end{tabular}

Table.2 Effect of inoculation of PGPRM on graft characters of cashew seedlings under poly house condition

\begin{tabular}{|c|c|c|c|}
\hline Treatments & $\begin{array}{c}\text { Recovery of Graftable } \\
\text { Seedlings } \\
(\%) 75 \text { DAS }\end{array}$ & $\begin{array}{c}\text { Days taken for sprout } \\
\text { Initiation after } \\
\text { grafting }\end{array}$ & $\begin{array}{c}\text { Success of } \\
\text { Grafts }(\%) 45 \\
\text { DAG }\end{array}$ \\
\hline T1 - Control & $80.33^{\mathrm{g}}$ & $18.17^{\mathrm{a}}$ & $75.67^{\mathrm{g}}$ \\
\hline $\mathrm{T} 2$ - Azotobacter chroococcum & $83.32^{\text {ef }}$ & $17.07^{\mathrm{b}}$ & $87.06^{b}$ \\
\hline T3 - Bacillus megaterium & $82.23^{\mathrm{f}}$ & $17.01^{b}$ & $82.26^{\mathrm{e}}$ \\
\hline T4- Glomus fasciculatum & $85.63^{\mathrm{cd}}$ & $16.17^{\mathrm{bc}}$ & $83.20^{\mathrm{d}}$ \\
\hline T5 - Pseudomonas fluorescens & $84.23^{\mathrm{de}}$ & $15.83^{\mathrm{c}}$ & $83.64^{\mathrm{d}}$ \\
\hline T6 - Trichoderma viride & $86.11^{\mathrm{cd}}$ & $14.67^{\mathrm{d}}$ & $85.28^{c}$ \\
\hline $\begin{array}{l}\text { T7-Azotobacter chroococcum }+ \\
\text { Bacillus megaterium }\end{array}$ & $85.63^{\mathrm{cd}}$ & $13.42^{\mathrm{ef}}$ & $87.12^{b}$ \\
\hline $\begin{array}{l}\text { T8-Azotobacter chroococcum }+ \\
\text { Glomus fasciculatum }\end{array}$ & $85.32^{\mathrm{cd}}$ & $13.58^{\mathrm{e}}$ & $86.71^{\mathrm{b}}$ \\
\hline $\begin{array}{l}\text { T9-Azotobacter chroococcum + } \\
\text { Pseudomonas fluorescens }\end{array}$ & $90.21^{\mathrm{a}}$ & $12.67^{\mathrm{efgh}}$ & $81.52^{f}$ \\
\hline $\begin{array}{l}\text { T10-Azotobacter chroococcum }+ \\
\text { Trichoderma viride }\end{array}$ & $90.01^{\mathrm{a}}$ & $12.25^{\text {ghi }}$ & $90.36^{\mathrm{a}}$ \\
\hline $\begin{array}{l}\text { T11 - Bacillus megaterium + Glomus } \\
\text { fasciculatum }\end{array}$ & $89.22^{\mathrm{a}}$ & $11.67^{\mathrm{hi}}$ & $90.34^{\mathrm{a}}$ \\
\hline $\begin{array}{l}\text { T12-Bacillus } \quad \text { megaterium } \\
\text { Pseudomonas fluorescens }\end{array}$ & $88.26^{\mathrm{ab}}$ & $11.75^{\text {hi }}$ & $87.23^{\mathrm{b}}$ \\
\hline 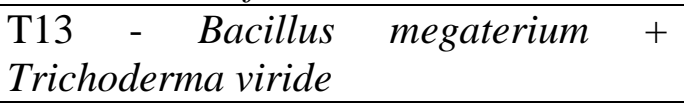 & $86.78^{\mathrm{bc}}$ & $11.42^{\mathrm{i}}$ & $85.29^{c}$ \\
\hline $\begin{array}{l}\text { T14-Pseudomonas } \quad \text { fluorescens+ } \\
\text { Trichoderma viride }\end{array}$ & $85.25^{\mathrm{cd}}$ & $13.25^{\mathrm{efg}}$ & $85.26^{\mathrm{c}}$ \\
\hline $\begin{array}{l}\text { T15 - Glomus } \\
\text { Trichoderma viride }\end{array}$ & $86.72^{\mathrm{bc}}$ & $12.42^{\text {fghi }}$ & $85.49^{c}$ \\
\hline $\mathrm{CD}(\mathbf{P}=\mathbf{0 . 0 5})$ & 0.66 & 0.73 & 0.20 \\
\hline
\end{tabular}

Note: PGPRM = Plant Growth Promoting Rhizo microorganisms. DAS = days after sowing. DAG = Days After Grafting. 
Maximum percentage recovery of graftable seedlings was recorded in the treatment receiving Azotobacter chroococcum with Psuedomonas fluorescens (90.21) followed by the treatment inoculated with Azotobacter chroococcum and Trichoderma viride 90.01) and the treatment receiving Bacillus megaterium with Glomus fasciculatum (89.22).

Minimum recovery of graftable seedlings was recorded in control (80.33).

\section{Days taken for sprout initiation}

The data on number of days taken for sprout initiation in scion is presented in Table 2 .

Minimum number of days taken for sprout initiation in the scion after grafting was observed in the treatment inoculated with Bacillus megaterium with Trichoderma viride (11.42) followed by the treatment which received Bacillus megaterium with Glomus fasciculatum (11.67) and Bacillus megaterium with Psuedomonas fluorescens (11.75).

Maximum number of days taken for sprout initiation was recorded in control (18.17).

\section{Success of grafts $(\%)$}

The data on success of grafts, 45 DAG is presented in Table 2.

Maximum percentage of success of grafts was obtained in the treatment inoculated with Azotobacter chroococcum with Trichoderma viride (90.36) followed by Bacillus megaterium with Glomus fasciculatum (90.34) and Bacillus megaterium with Psuedomonas fluorescens (87.23). Minimum percentage of success of grafts was recorded in the treatment control (75.67).

The maximum stem girth of cashew root stocks at 45,75 DAS and 45 DAG was obtained in the treatment receiving Bacillus megaterium with Glomus fasciculatum. At 45 DAS the next highest stem girth was observed in the treatments receiving Pseudomonas fluorescens with Trichoderma viride and Glomus fasciculatum with Trichoderma viride. Whereas at 75 DAS as well as at 45 DAG the next highest stem girth was obtained in the treatment receiving Bacillus megaterium with Pseudomonas fluorescens followed by the treatment which received Azotobacter chroococcum with Glomus fasciculatum.

The minimum stem girth of cashew seedlings was noticed in control. Similar reports of increase in growth parameters like plant height, stem diameter and shoot biomass by inoculation of Gigaspora margarita were reported by Balakrishna and Bagyaraj, (1994); Aneesha and Sathimoorthy (1997) in papaya, and Vinayaka and Bagyaraj (1990) in trifoliate orange and Lakshmipathy et al., (2000) in cashew.

Maximum root length of cashew seedlings at 75 DAS was obtained in the treatments receiving Azotobacter chroococcum with Bacillus megaterium followed by Bacillus megaterium with Glomus fasciculatum and Glomus fasciculatum alone, lowest root length was recorded in control.

Shanmugam (1981) also observed similar effects of increased growth and root length in six months old Citrus aurantifolia seedlings when they were inoculated with Glomus mosseae or Glomus etunicatum. Dileep Kumar and Dube (1992) obtained similar results by VAM inoculation to tomato and egg plants.

Increase in height and better root development of soybean plants by inoculation of Trichoderma harzianum was also reported by Daiho and Upadhyay (1995). 
Effect of PGPRM on shoot and root biomass of cashew seedling

Maximum shoot fresh and dry weight was observed in the treatment receiving Pseudomonas fluorescens with Trichoderma viride followed by Glomus fasciculatum alone.

Maximum root fresh and dry weight was obtained in the treatment receiving Bacillus megaterium with Trichoderma viride followed by the treatments which received Pseudomonas fluorescens with Trichoderma viride and Bacillus megaterium with Pseudomonas fluorescens. The minimum shoot and root fresh as well as dry weight was noticed in control. Similar results of increased fresh and dry weight of shoot and root was obtained by Lakshmipathy (2000) in cashew, Windham (1986) in tomato and tobacco, Chanway (1995) in Tsugaheterophylla and Meyer and Linderman (1986) in clover by inoculation with Pseudomonas putida and VAM.

Increase in growth parameters of cashew seedlings observed in the present study due to inoculation of PGPR microorganisms might be due to the mechanisms of production of growth regulating metabolites by the microbial agents (Mroz et al., 1994; Glick, 1995), greater availability of nutrients by application of nitrogen fixers, $\mathrm{P}$ solubilizers, $\mathrm{P}$ mobilizers etc. (Rudresh et al., 2005; Somani et al., 1990; Pawar and Pawar 1998), synergistic interaction among the PGPR microorganisms which might have additive effect on growth and biomass of cashew seedlings (Raj et al., 1981; Mayo et al., 1986; Mosse, 1957), by increasing the deleterious effect on pathogens in presence of beneficial microorganisms and biocontrol agents. (Kumar et al., 1998; Rakeshkumar et al., 2004), by proliferation of beneficial PGPR microorganisms in the cashew nut rhizosphere
(Oblisami et al., 1985; Patil et al., 1979; Lakshmipathy et al., 2000 and Radhika et al., 2005) and by biological control of plant pathogens (Krishna and Bagyaraj, 1993; Rakesh Kumar et al., 2004 and Sunandadeene et al., 2004).

\section{References}

Aneesa, R. M. S and Sathiyamoorthy, S., 1997, Effect of organic and biofertilizers on root enzyme activity, nematode, total biomass and growth enhancement of papaya CV.CO - 6, South Indian Hort., 45: 217 - 223.

Balakrishna and Bagyaraj, D. J., 1994, Selection of efficient vesicular arbuscular mycorrhizal fungi for inoculating the mango root stock $\mathrm{Cv}$. Nekkere. Scientia Horticulturae, 59: 69 $-73$.

Chanway, C.P., 1995, Differential response of western hemlock from low and high elevations to inoculation with plant growth promoting Bacillus polymyxa. Soil Biol. Biochem., 27: 767-775.

Daiho, L. And Upadhyaya, D. N., 1995, Growth stimulating effects of Trichoderma harzianumon soybean. $J$. Soil. Biol. Ecol., 15: 46 - 47.

Dileep Kumar, B. S. and Dube, H. C., 1992, Seed bacterisation with fluorescent Pseudomonads for enhanced plant growth yield and disease control. Soil Biol. and Biochem., 24: $539-542$.

Glick, B.R., 1995, The enhancement of plant growth of free living bacteria. Can. J. Microbiol., 41: 109-117.

Johnson, L.F. and Curl, E.A., 1972, Methods for research on the ecology of soil borne plant pathogens. Burgess, Minneapolis, pp. 247.

Katzenelson, H. and Bose, B., 1959, Metabolic activity and phosphate dissolving capability of bacterial isolates from wheat roots, rhizosphere 
and non rhizosphere soil. Can. $J$. Microbiol., 5: 79 - 85 .

Krishna, K.R. and Bagyaraj, D.J., 1993, Interaction between Glomus fasciculatum and Sclerotiumrolfsii in peanut. Can. J. Bot.,61: 2349-2351.

Kumar, D. P., Hegde, M., Bagyaraj., D. J. and Madhava Rao, A. R. 1998, Influence of biofertilizers on the growth of cashew (Anacardium occidentale L.) root stocks. The cashew, 12: 3-9.

Lakshmapathy, R., Balakrishna, A. N., Bagyaraj, D. J., and Kumar, D. P., 2000. Symbiotic response of cashew root stock to different VAM - fungi. The Cashew, 21: 20 - 22.

Mayo, K., Davis, R.E. and Motto, J., 1986, Stimulation of germination of spores of Glomus versiforme by spore associated bacteria. Mycologia, 78: 426-431.

Meyer, J.R. and Linderman, R.G., 1986, Response of subterranean clover to dual inoculation with vesicular arbuscular mycorrhizal fungi and a plant growth promoting bacterium Pseudomonas putida. Soil Biol. Biochem., 18: 185190.

Mosse, B., 1957, Growth and chemical composition of Mycorrhizal and non mycorrhizal apples. Nature, (London), 179: 922 - 924.

Mroz, A., Martiniuk, S. and Kus, J., 1994, Response of winter wheat to seed applied microorganisms. Phytopathol polonica, 19: $15-20$.

Oblisami, G., Krishnan, P. S., Pappaiah, C. M. and Shanmugavelu, K. G., 1985, Effect of Azotobacter inoculants and growth regulators on the growth of cashew. Acta Horticulturae, 108: 40 45.

Patil, R. B., Rajashekarappa, b. J., Vishwanatha, D. P. and Shantaram, M. V., 1979, Solubilization and immobilization of phosphate by some microorganisms and phosphorus availability to plants. Bull. Indian. Soc. Sci., 12: $550-556$.

Pawar, P. P. and Pawar, V. S., 1998, Response of pigeon pea CV ICPL -87 to application of phosphorus and $\mathrm{P}$ solubilizers. J. Maharashtra Agricultural University, 23: 126 -128.

Raj, J., Bagyaraj, D.J. and Manjunath, A, 1981, Influence of soil inoculation with vesicular arbuscular mycorrhiza and a phosphate solubilizing bacterium on plant growth and 32p uptake. Soil Biol. Biochem., 13: 105-107.

Rakesh Kumar, B.L., Jalali and Harichand, 2004, Interaction between VAmycorrhizal fungi and soil-borne plant pathogens of chickpea. Legume Res., 27: 19-26.

Rudresh, D.L., Shivaprakash, M.K. and Prasad, R.D., 2005, Tricalcium phosphate solubilizing abilities of Trichoderma spp. in relation to $\mathrm{P}$ uptake and growth and yield parameters of chickpea (Cicer arietinum L.). Can. J. Microbiol., 51: 217 - 222.

Shanmugam, N., Chandrababu, R. and Thalamuthu, C.M, 1981, Studies on the response of acid lime (Citus aurantifolia) to VA Mycorrhizae. Curr. Sci., 50: $772-773$.

Somani, L.L., Bhandari, S.C., Vyas, K.K. and Saxena, S.N., 1990, Biofertilizers, Scientific publishers, Jodhpur, pp. 271295.

Sperber, J.I., 1958, The incidence of apatite solubilizing organisms in the rhizosphere and soil. Aust. J. Agric. Res., 9: 778 - 781 .

Strobel, G. A. and Nachmias, A., 1985, Agrobacterium rhizogenes promotes the initial growth of bare root stock of almond. J. Gen. Microbiol., 131: 1245 1249.

Subba Rao, N. S., 1995, Soil microorganisms and plant growth (third edition), pp 77 293, oxford and IBH publishing 
company, New Delhi.

Sunanda Deene, Rajkumar Garampalli, and Reddy, C.N., 2004, Influence of dual inoculation with vesicular arbuscular mycorrhiza (Glomus aggregatum) and Fusarium udum on plant vigour and wilt disease incidence of pigeonpea. Phytopathol. 54: 23-29.

Sundara Rao, W. V. B., Mann, M. S., Paul, N. B and Mathur, S. P., 1963, Bacterial inoculation experiments with special reference to Azotobacter. Indian $J$. Agric. Sci., 33: 279 - 289. agriculture and in organics. In: soil health and crop production, Thampan, P. K. (ed.), peekay tree crops development foundation, Cochin, pp. $151-184$.

Vinayak, K. and Bagyaraj. D. J., 1990, Selection of efficient VA Mycorrhizae screened for Troyer citrange. Biol. Fert. Soil, 9: $311-314$.

Windham, W.T., Elad, Y. and Baker, R., 1986, A mechanism of increased plant growth induced by Trichoderma spp. Phytopathol, 76: 18-21.

Verma, L. M., 1993, Biofertilizers in

\section{How to cite this article:}

Ranjani, S.N., L. Krishna Naik and Kushala, G. 2017. Study of Effect of Plant Growth Promoting Rhizo Microorganisms on Success Rate of Cashew Grafts. Int.J.Curr.Microbiol.App.Sci. 6(12): 3704-3713. doi: https://doi.org/10.20546/ijcmas.2017.612.427 